\title{
PERAN BALAI PEMUDA DAN OLAHRAGA YOGYAKARTA DALAM UPAYA PENGEMBANGAN KEWIRAUSAHAAN PEMUDA UNTUK MENDUKUNG KETAHANAN EKONOMI KELUARGA ( Studi Tentang Persepsi Peserta Kegiatan Pelatihan Keterampilan BPO DIY)
}

\author{
Muhammad Iskandar Zulkarnain \\ Sekretariat Pemerintah Kabupaten Paser (Setkab) \\ Provinsi Kalimantan Timur \\ zulkarnaenmuhammad333@yahoo.co.id
}

\begin{abstract}
This research aimed to analyzed the programs and activities proposed by the Center for Youth and Sports in the Province of Yogyakarta Special Region in promoting entrepreneurship among the youth, and to analyzed as well as the aspect of the family economic resilience of the participants attending the catfish farming training program held by the Center for Youth and Sports in the Province of Yogyakarta Special Region.

The method employed was the combined method of descriptive qualitative methods and quantitative methods by conducting observation, structured interviews and library research. For assessing the roles of the Center for Youth and Sports in the Province of Yogyakarta Special Region in promoting entrepreneurship among the youth, was used 7 standards of entrepreneurship promotion efforts among the youth according to the Government Regulation No. 41/2011, while to assessed the family economic resilience of the participants attending the skill training program held by the Center for Youth and Sports in the Province of Yogyakarta Special Region were used the data on the income generated by each participants that were met with the standard minimum wage for cities/ regencies.

The result of the research showed that the seven aspects of the entrepreneurship promotion efforts among the youth, the Center for Youth and Sports in the Province of Yogyakarta Special Region were considered to played roles in the aspects of training and internship, while for the aspects of guidance, assistance, partnership and promotion were considered not performing its roles. Finally, for the aspects of capital assistance and access, its roles in these aspects were considered not optimal. It was based the fact that the Center for Youth and Sports in the Province of Yogyakarta Special Region had not managed to established a capital institution which helped to provided the funds for the purpose of promoting entrepreneurship among the youth even though the Center for Youth and Sports at the central level had already provided the initial capital assistance for the cadre of young entrepreneurs.
\end{abstract}

Keyword: Roles, Entrepreneurship and Family Economic Resilience

\begin{abstract}
ABSTRAK
Tujuan penelitian ini untuk menganalisis Program dan Kegiatan yang disusun oleh Balai Pemuda dan Olahraga Provinsi DIY dalam upaya pengembangan kewirausahaan pemuda, kemudian untuk menganalisis peran Balai Pemuda dan Olahraga Provinsi DIY dalam upaya pengembangan kewirausahaan pemuda dan yang terakhir untuk menganalisis aspek ketahanan ekonomi keluarga para alumni kegiatan pelatihan keterampilan budidaya lele yang digagas oleh Balai pemuda dan Olahraga Provinsi DIY.
\end{abstract}


Metode yang digunakan yakni metode penggabungan antara metode deskriftif kualitatif dan metode kuantitatif, dengan menggunakan observasi, wawancara terstruktur dan studi pustaka. Untuk mengukur peran Balai Pemuda dan Olahraga Provinsi DIY dalam upaya pengembangan kewirausahaan pemuda digunakan 7 standar pengembangan kewirausahaan pemuda menurut Peraturan Pemerintah Nomor 41 tahun 2011, selain itu guna mengukur ketahanan ekonomi keluarga alumni kegiatan pelatihan keterampilan yang diselenggarakan Balai Pemuda dan Olahraga Provinsi DIY digunakan data pendapatan para alumni yang dicocokkan dengan standar upah minimum kabupaten.

Hasil penelitian menunjukkan bahwa 7 (tujuh) aspek pengembangan kewirausahaan pemuda, BPO Provinsi DIY telah dinilai berperan pada aspek pelatihan dan pemagangan, namun pada aspek pembimbingan, pendampingan, kemitraan dan promosi dinilai bahwa BPO Provinsi DIY belum menjalankan perannya, sementara itu untuk aspek bantuan dan akses permodalan BPO provinsi DIY dinilai belum sepenuhnya berperan. Hal ini didasarkan fakta bahwa BPO Provinsi DIY belum berhasil membentuk lembaga permodalan kewirausahaan pemuda meskipun BPO sudah memberikan bantuan permodalan awal bagi kader wirausahawan muda.

\section{Kata Kunci: Peran, Kewirausahaan dan Ketahanan Ekonomi Keluarga.}

\section{PENGANTAR}

Upaya pengembangan wirausaha di Indonesia telah lama dilakukan, baik oleh lembaga pemerintah maupun lembaga non pemerintah (Perguruan Tinggi, LSM, BUMN, Perbankan, dan Masyarakat), terutama sejak krisis ekonomi melanda Indonesia pada tahun 1997. Meskipun demikian, pengembangan wirausaha bukan sekedar persoalan bisnis, akan tetapi kewirausahaan merupakan persoalan sikap mental yang perlu dibangun dan dipupuk serta dapat diaplikasikan pada pelbagai sektor kehidupan.

Berkaitan dengan upaya pengembangan kewirausahaan di Indonesia, menurut Peraturan Menteri Negara Pemuda dan Olahraga Nomor 22 Tahun 2010 Tentang Rencana Strategis Kementerian Pemuda dan olahraga Tahun 2010-2014 bahwa pembangunan kepemudaan dilakukan melalui proses fasilitasi segala hal yang berkaitan dengan pelayanan kepemudaan, menitikberatkan kepada proses penyadaran, pemberdayaan, dan pengembangan kepemudaan. Pengembangan kepemudaan dilaksanakan dalam rangka meningkatkan jiwa kepemimpinan, kewirausahaan, dan kepeloporan pemuda, sehingga pada gilirannya dapat melahirkan pemuda yang maju yakni pemuda yang berkarakter, berkapasitas, dan berdaya saing (Kementerian Pemuda dan Olahraga, 2010).

$$
\text { Program peningkatan upaya }
$$
pengembangan kewirausahaan pemuda merupakan salah satu dari sekian banyak program yang diamanatkan oleh Kementerian Pemuda dan Olahraga Republik Indonesia kepada instansi daerah yang menangani urusan kepemudaan baik di level provinsi maupun di level kabupaten atau kota di Indonesia. Pengembangan kewirausahaan pemuda merupakan kebijakan lintas bidang dan lintas sektor. Dengan sifatnya yang lintas bidang dan lintas sektor tersebut, Kemenpora perlu melibatkan para stakeholders terkait kepemudaan dalam pelaksanaan kebijakan kewirausahaan pemuda. Berdasarkan identifikasi yang dilakukan Kemenpora dan Bappenas Tahun 2010, setidaknya terdapat 9 kementerian/lembaga yang melaksanakan kegiatan kewirausahaan pemuda.

Berdasarakan penelusuran awal peneliti, ditemukan bahwa jumlah wirausaha muda di Provinsi DIY masih minim, sementara itu pelaksanaan program dan kegiatan yang berorientasi pada upaya pengembangan kewirausahaan pemuda setiap tahunnya 


\section{Muhammad Iskandar Zulkarnain -- Peran Balai Pemuda Dan Olahraga Yogyakarta Dalam Upaya Pengembangan Kewirausahaan Pemuda Untuk Mendukung Ketahanan Ekonomi Keluarga (Studi Tentang Persepsi Peserta Kegiatan Pelatihan Keterampilan BPO DIY)}

selalu digelar oleh BPO Provinsi DIY. Di sinilah pentingnya penelitian tentang bagaimana peran Balai Pemuda dan Olahraga Provinsi DIY dalam upaya pengembangan kewirausahaan pemuda dalam mendukung ketahanan ekonomi keluarga. Berangkat dari fenomena yang peneliti kemukakan di atas, peneliti tertarik untuk mengkajinya ke dalam tesis ini dengan judul Peran Balai Pemuda dan Olahraga (BPO) Provinsi Daerah Istimewa Yogyakarta Dalam Upaya Pengembangan Kewirausahaan Pemuda Untuk Mendukung Ketahanan Ekonomi Keluarga.

Penelitian ini dilakukan dengan tujuan untuk : pertama, untuk mengetahui peran BPO Provinsi DIY dalam upaya pengembangan kewirausahaan pemuda, dan kedua, untuk mengkaji aspek ketahanan ekonomi keluarga para alumni kegiatan pelatihan keterampilan budidaya lele yang digagas oleh BPO Provinsi DIY.

Penentuan informan dalam penelitian ini menggunakan pendekatan purpossive sample yaitu dengan sengaja menentukan informan berdasarkan kapabilitas informan dan kebutuhan penelitian. Informan dalam penelitian ini yaitu: pertama, satu orang mantan penjabat kepala seksi pemuda saat kegiatan yang diteliti dilaksanakan sebagai informan yang menjelaskan bagaimana pelaksanaan kegiatan pelatihan keterampilan; kedua, penjabat kepala seksi pemuda saat ini dan seorang staf pemuda yang mengetahui proses pelaksanaan kegiatan pelatihan keterampilan ketiga, tiga orang alumni peserta kegiatan pelatihan keterampilan.

Penentuan responden dalam penelitian ini digunakan untuk mengetahui peran BPO dalam upaya pengembangan kewirausahaan pemuda dengan menggunakan analisis skala Likert.
Sebenarnya ada 60 orang peserta kegiatan pelatihan keterampilan budidaya lele yang diselenggarakan oleh BPO Yogyakarta tahun 2012, namun dari total populasi tersebut yang dapat teridentifikasi keberadaannnya sebanyak 33 orang dan yang masih teridentifikasi berada di DIY hanya 30 orang sehingga jika dihitung maka: $\mathrm{n}=30,48$ (dibulatkan menjadi 30).

Dalam penelitian ini, pengumpulan data dilakukan dengan metode observasi, wawancara, penyebaran kuesioner dan studi pustaka. Analisis data dalam penelitian ini melalui tri anggulasi. Data yang diperoleh peneliti selalu dibandingkan dengan yang lainnya. Demikian juga dengan observasi yang dilakukan peneliti juga dikomparasikan dengan hasil wawancara dan hasil kuesioner (Sugiyono, 2009).

\section{PEMBAHASAN}

Pengembangan kewirausahaan pemuda merupakan salah satu kegiatan pengembangan potensi keterampilan dan kemandirian berusaha. Kepemudaan dan kewirausahaan merupakan dua hal yang berkaitan dan tidak bisa dipisahkan. Hal tersebut tergambar dalam penjabaran Undang-undang Nomor 40 Tahun 2009 Tentang Kepemudaan. Pemerintah banyak mengaitkan aspek kepemudaan dengan bidang kewirausahaan. Dengan adanya jiwa kewirausahaan di dalam diri pemuda maka jiwa kemandirian diharapkan dapat tumbuh. Yang dimaksud dengan kemandirian di sini adalah pemuda tidak hanya bergantung pada sektor formal namun juga dapat mengembangkan kreativitasnya pada sektor informal seperti kewirausahaan.

\section{Teori peran}

Makna peranan menurut Soekanto (2005:243) adalah "peran (role) merupakan 
aspek dinamis dari suatu kedudukan atau status.” Seseorang yang melaksanakan hak dan kewajibannya sesuai dengan kedudukan, maka ia dinilai telah menjalankan suatu peran. Peranan dan kedudukan saling berkaitan erat dan tidak dapat dipisahkan karena mereka saling bergantung satu sama lainnya.

Peran mencakup tiga hal: Pertama, peranan meliputi norma-norma yang dihubungkan dengan posisi atau tempat seseorang dalam masyarakat. Peran dimaksud adalah rangkaian peraturan-peraturan yang membimbing seseorang dalam kehidupan masyarakat. Kedua, peranan adalah suatu konsep tentang apa yang dapat dilakukan oleh individu dalam masyakarat sebagai organisasi. Ketiga, peranan juga dapat dikatakan sebagai perilaku individu yang penting bagi struktur sosial masyarakat.

Berdasarkan beberapa pengertian di atas, maka dapat disimpulkan bahwa yang dimaksud dengan peran adalah segala tindakan yang dilakukan oleh seseorang atau lembaga yang mempunyai kedudukan tertentu dalam masyarakat dalam melaksanakan hak dan kewajiban yang dimilikinya sesuai dengan kedudukan dan fungsinya. Untuk itu yang dimaksud dengan peran Balai Pemuda dan Olahraga Provinsi DIY adalah segala tindakan dan kewajiban yang dilaksanakan oleh Balai Pemuda dan Olahraga Provinsi DIY guna mewujudkan pengembangan kewirausahaan pemuda.

\section{Teori pengembangan}

Peraturan Pemerintah Nomor 41 Tahun 2011 Tentang Pengembangan Kewirausahaan dan Kepeloporan Pemuda serta Penyediaan Prasarana dan Sarana Kepemudaan menjelaskan bahwa yang dimaksud dengan pengembangan kewirausahaan pemuda adalah kegiatan mengembangkan potensi keterampilan dan kemandirian berusaha Sementara itu tolak ukur pengembangan kewirausahaan pemuda sebagaimana diamanatkan dalam Peraturan Pemerintah Nomor 41 Tahun 2011 tersebut, lebih spesifik pada pasal 19 yang dinyatakan bahwa pengembangan kewirausahaan pemuda dilaksanakan melalui: (1) pelatihan; (2) pemagangan; (3) pembimbingan; (4) pendampingan; (5) kemitraan; (6) promosi; (7) bantuan dan akses spermodalan. Tujuh aspek inilah yang kemudian peneliti jadikan sebagai indikator untuk mengukur peran Balai Pemuda dan Olahraga Provinsi DIY dalam upaya pengembangan kewirausahaan pemuda.

\section{Teori kewirausahaan}

Kewirausahaan memiliki pengertian sifat, ciri dan watak seseorang yang memiliki kemauan dalam mewujudkan gagasan inovatif kedalam dunia nyata secara kreatif. Sedangkan yang dimaksudkan dengan seorang wirausahawan adalah orang-orang yang memiliki kemampuan melihat dan menilai kesempatan bisnis; mengumpulkan sumber daya-sumber daya yang dibutuhkan untuk mengambil tindakan yang tepat, mengambil keuntungan serta memiliki sifat, watak dan kemauan untuk mewujudkan gagasan inovatif ke dalam dunia nyata secara kreatif dalam rangka meraih peningkatan pendapatan.

\section{Teori kepemudaan}

Kategori usia pemuda ini masih menyisakan polemik. Pasalnya penetapan usia pemuda ini bertentangan antara satu undangundang dengan Undang-undang lainnya, seperti UU No.23 Tahun 2002 Tentang 
Muhammad Iskandar Zulkarnain -- Peran Balai Pemuda Dan Olahraga Yogyakarta Dalam Upaya
Pengembangan Kewirausahaan Pemuda Untuk Mendukung Ketahanan Ekonomi Keluarga (Studi Tentang Persepsi Peserta Kegiatan Pelatihan Keterampilan BPO DIY)

Perlindungan Anak, pasal 1 ayat (1) dan UU No.13 Tahun $2003 \backslash$ Tentang Ketenagakerjaan, pasal 1 ayat (26) yang menyebutkan bahwa yang dimaksud dengan anak adalah seseorang yang belum berusia 18 tahun. Mengacu kepada kedua undang-undang ini, maka seharusnya usia pemuda dimulai pada usia 18 tahun ke atas.

Menurut World Healt Organization (WHO) sebagai badan kesehatan dunia mendefinisikan pemuda berdasarkan umur antara 10-24 tahun. Adapun menurut Undangundang Nomor.40 Tahun 2009 Tentang Kepemudaan, “pemuda adalah warga negara yang memasuki periode penting masa pertumbuhan yang digolongkan dalam kelompok umur 16-30 tahun.” Dalam penelitian ini peneliti menggunakan acuan UndangUndang nomor 40 Tahun 2009 Tentang Kepemudaan yang membatasi rentang usia 16-30 tahun sebagai kriteria pemuda, dan kreteria ini pula yang digunakan oleh Balai Pemuda dan Olahraga DIY dalam rekrutmen peserta pelatihan.

\section{Teori ketahanan ekonomi keluarga}

Untuk mengkaji ketahanan ekonomi keluarga tidak terlepas dari pendefenisian keluarga secara tepat. Menurut Friedman (1998:43) mendefinisikan "keluarga sebagai kumpulan 2 (dua) orang atau lebih yang hidup bersama dengan keterikatan aturan dan emosional serta individu yang mempunyai peran masing-masing yang merupakan bagian dari keluarga”.

Mengacu kepada beberapa konsep di atas, maka peneliti berpendapat bahwa ketahanan ekonomi keluarga adalah kondisi dinamik suatu keluarga yang berisi ketangguhan dan keuletan yang mengandung kemampuan mengembangkan kekuatan keluarga dalam menghadapi dan mengatasi segala tantangan, ancaman, hambatan serta gangguan yang datang dari luar maupun dalam, yang langsung maupun tidak langsung membahayakan kelangsungan kehidupan ekonomi keluarga. Dewasa ini sedang dikembangkan suatu kebijaksanaan dan strategi pembangunan melalui upaya intervensi dari dalam melalui pemberdayaan keluarga sebagai unit terkecil dari kehidupan bermasyarakat dan bernegara.

Ketahanan ekonomi diukur dengan jumlah penghasilan atau pengeluaran per rumah tangga dalam jangka waktu tertentu dibandingkan dengan batas kemiskinan.

Ketahanan ekonomi keluarga dapat diukur dari tingkat kemiskinan dari keluarga tersebut. Menurut Word Bank (2006: 1-4) definisi kemiskinan dibagi menjadi dua kategori, yaitu kategori sangat miskin yang dapat dilihat dari indikator pendapatan per kapita per hari sebesar kurang dari US \$1, kategori miskin dilihat dari indikator pendapatan per kapita per hari antara US \$1 hingga US \$2, dan kategori tidak miskin dilihat dari indikator pendapatan per kapita per hari sebesar lebih dari US \$2.

Seseorang dapat dikategorikan miskin jika diukur dari pendapatan yang diperoleh kurang atau masih di bawah standar dari UMK yang ditetapkan oleh pemerintah setempat, sedangkan kategori tidak miskin jika pendapatan lebih dari UMK yang sudah ditetapkan. Sebagaimana Surat Keputusan Gubernur DIY Nomor 279/KEP/2013 Tentang Upah Minimum Kabupaten/Kota Tahun 2014 di Daerah Istimewa Yogyakarta adalah: (1) UMK Yogyakarta; (2) Rp. 1.173.300; (3) UMK Sleman Rp. 1.127.000; (4) UMK Bantul Rp. 1.125.500; (5) UMK Kulon Progo Rp. 
1.0669.000; (6) UMK Gunung Kidul Rp. 988.500.

Dalam penelitian ini, ketahanan ekonomi keluarga yang diamati adalah dalam hubungannya dengan usaha yang dikembangkan oleh wirausahawan muda alumni kegiatan pelatihan keterampilan pemuda pada Balai Pemuda dan Olahraga DIY dalam usaha meningkatkan pendapatan keluarga guna terpenuhinya semua kebutuhan keluarga. Untuk mengetahui hubungan tersebut ditinjau dari besarnya pendapatan dibandingkan dengan standar UMK masingmasing daerah.

\section{Visi Pemerintah Provinsi DIY}

Visi Pemerintah Provinsi DIY adalah: Daerah Istimewa Yogyakarta Yang Lebih Berkarakter, Berbudaya, Maju, Mandiri dan Sejahtera Menyongsong Peradaban Baru. Daerah Istimewa Yogyakarta yang lebih berkarakter dimaknai sebagai kondisi masyarakat yang lebih memiliki kualitas moral yang positif, memanusiakan manusia sehingga mampu membangun kehidupan yang bermanfaat bagi dirinya sendiri dan bagi orang lain.

\section{Peran BPO Provinsi DIY Dalam Upaya Pengembangan Kewirausahaan Pemuda}

\section{Peran pelatihan}

Secara khusus Peraturan Pemerintah Nomor 41 Tahun 2011 Tentang Pengembangan Kewirausahaan dan Kepeloporan Pemuda serta Penyediaan Prasarana dan Sarana Kepemudaan tidak mengatur apakah ketujuh point pengembangan kewirausahaan pemuda tersebut merupakan item-item yang integral dalam suatu kegiatan secara utuh sehingga setiap kegiatan diharuskan mencakup ketujuh aspek tersebut, ataukah boleh berdiri sendiri sebagai sebuah kegiatan. Namun peneliti berkesimpulan bahwa justru karena Peraturan Pemerintah Nomor 41 Tahun 2011 tersebut tidak mengatur secara rinci membuat pelaksanaannya lebih fleksibel, artinya boleh dipahami setiap kegiatan yang dilaksanakan terkait upaya pengembangan kewirausahaan pemuda harus mencakup ketujuh point yang diamanatkan atau boleh juga dipahami bahwa ketujuh point tersebut bisa berwujud kegiatan yang berdiri sendiri.

Gambaran peran BPO provinsi DIY dalam pelaksanaan aspek pelatihan juga peneliti amati dari hasil kuesioner. Berikut hasil penelitian berupa data-data dari jawaban responden dan hitungan dengan menggunakan skala Likert, adapun hasilnya seperti berikut: jumlah skor ideal (kriterium) untuk seluruh item $=5 \times 90=450$, seandainya semua menjawab sangat setuju (SS). Jumlah yang diperoleh dari penelitian $=338$. Jadi berdasarkan data tersebut maka tingkat persetujuan stakeholder mendekati jawaban setuju, bahwa BPO Provinsi DIY sudah menjalankan perannya dalam aspek pelatihan, artinya bahwa BPO dianggap menjalankan perannya dalam aspek pelatihan.

\section{Peran pemagangan}

Peran kedua dari pengembangan kewirausahaan sebagaimana yang diamananatkan oleh Peraturan Pemerintah Nomor 41 Tahun 2011 Tentang Pengembangan Kewirausahaan dan Kepeloporan Pemuda serta Penyediaan Prasarana dan Sarana Kepemudaan adalah pemagangan. Terkait dengan peran ini dapat dijelaskan bahwa BPO Provinsi DIY tidak secara khusus memfasilitasi 
Muhammad Iskandar Zulkarnain -- Peran Balai Pemuda Dan Olahraga Yogyakarta Dalam Upaya Pengembangan Kewirausahaan Pemuda Untuk Mendukung Ketahanan Ekonomi Keluarga (Studi Tentang Persepsi Peserta Kegiatan Pelatihan Keterampilan BPO DIY)

aspek pemagangan melalui kegiatan tersendiri, melainkan aspek pemagangan tersebut diintegrasikan di dalam kegiatan pelatihan keterampilan bagi pemuda.

Dari keterangan di atas tergambar bahwa BPO provinsi DIY sudah mengimplementasikan peran kedua dari pengembangan kewirausahaan sebagaimana yang diamanatkan dalam Peraturan Pemerintah Nomor 41 Tahun 2011 tersebut.

Gambaran peran BPO provinsi DIY dalam pelaksanaan aspek pemagangan juga peneliti amati dari hasil kuesioner. Jumlah skor ideal (kriterium) untuk seluruh item $=$ 5 x $90=450$, seandainya semua menjawab sangat setuju (SS). Jumlah yang diperoleh dari penelitian $=338$. Jadi berdasarkan data tersebut maka tingkat persetujuan stakeholder mendekati jawaban setuju, artinya bahwa BPO dianggap menjalankan perannya dalam aspek pemagangan.

\section{Peran pembimbingan}

Pada peran pembimbingan ini menurut informasi yang diperoleh di lapangan bahwa peran ini terwadahi dalam sebuah kegiatan yang bernama "Pembinaan Inovasi Bisnis Bagi Pemuda”. Kegiatan ini merupakan kegiatan yang dibuat guna kepentingan persiapan mengikuti lomba inovasi bisnis bagi pemuda yang mengacu pada kegiatan di tingkat pusat dalam hal ini Kementerian Pemuda dan Olahraga. Untuk itu calon peserta lomba yang akan mewakili DIY dibina oleh BPO Provinsi DIY, sehingga faktanya kegiatan pembinaan inovasi bisnis bagi pemuda tersebut bukanlah sebagai kegiatan pembimbingan bagi para alumni kegiatan pelatihan keterampilan dalam rangka membimbing mereka menjadi wirausahawan, namun lebih pada aspek persiapan lomba yang akan diikuti.
Gambaran peran BPO provinsi DIY dalam pelaksanaan aspek pembimbingan juga dapat diamati dari hasil kuesioner dari jawaban responden. Jumlah skor ideal (kriterium) untuk seluruh item $=5$ × $90=450$, seandainya semua menjawab sangat setuju (SS). Jumlah yang diperoleh dari penelitian $=212$. Jadi berdasarkan data tersebut maka tingkat persetujuan stakeholder mendekati jawaban tidak setuju, atau BPO Provinsi DIY belum menjalankan perannya dalam aspek pembimbingan.

\section{Peran pendampingan}

Aspek selanjutnya adalah peran pendampingan. Pendampingan yang dimaksud adalah upaya yang dilakukan dalam mendampingi para pemuda dalam mengawali usahanya, sehingga setiap kendala-kendala yang dihadapi oleh para pemuda kaitannya dengan upaya pengembangan wirausaha melalui implementasi ide wirausaha yang mereka miliki dapat dicarikan solusinya dengan demikian akan mampu terhindar dari keputusasaan pemuda dalam berusaha.

Peran pendampingan diakui sebagai bagian yang belum terakomodir dalam kegiatan BPO Provinsi DIY selama ini. Alasan yang melatarbelakangi kondisi ini adalah terbatasnya pagu anggran yang tersedia guna mengakomodir kegiatan yang dimaksud.

Data lain yang diperoleh tentang peran BPO Provinsi DIY dalam pelaksanaan aspek pendampingan juga peneliti amati dari hasil kuesioner. Jumlah yang diperoleh dari penelitian $=212$. Jadi berdasarkan data tersebut maka tingkat persetujuan stakeholder mendekati jawaban tidak setuju, atau BPO Provinsi DIY belum menjalankan perannya dalam aspek pendampingan. 


\section{Peran kemitraan}

Peran kelima adalah peran kemitraan. Berdasar informasi yang didapat dalam Program dan Kegiatan BPO Provinsi DIY yang terkait dengan upaya pengembangan kewirausahaan pemuda, ditunjukkan bahwa BPO Provinsi DIY belum mengakomodir aspek ini dalam kegiatan yang diselenggarakan, alasannya sama dengan alasan mengapa peran pendampingan belum diakomodir yakni dikarenakan alasan keterbatasan pagu anggaran dan personil di BPO Provinsi DIY.

Di sisi lain informasi yang diperoleh tentang peran BPO Provinsi DIY dalam pelaksanaan peran kemitraan juga peneliti amati dari hasil kuesioner. Jumlah yang diperoleh dari penelitian $=204$. Jadi berdasarkan data tersebut maka tingkat persetujuan stakeholder mendekati jawaban tidak setuju, atau BPO Provinsi DIY belum menjalankan perannya dalam aspek kemitraan.

\section{Peran promosi}

Peran promosi merupakan hal penting dalam upaya mempromosikan usaha yang dikembangkan, sehingga akan mampu berdampak terhadap kemajuan usaha yang dikembangkan. Adapun kegiatan yang dianggap oleh BPO Provinsi DIY sebagai bagian dari implementasi aspek keenam atau aspek promosi termanivestasikan dalam kegiatan yang bernama Pameran Prestasi Hasil Karya Pemuda, sekalipun kegiatan ini bernama pameran namun lebih banyak berfungsi sebagai ajang pengenalan atau publikasi terhadap prestasi-prestasi yang diraih oleh pemuda di Provinsi DIY dalam semua bidang, bukan spesifik sebagai wadah promosi bagi usaha yang sedang dikembangkan oleh para pemuda. Jika ajang pameran tersebut diarahkan sebagai wadah promosi bagi usaha yang sedang dikembangkan pemuda, maka akan mampu memperluas akses pemasaran maupun akses kemitraan bagi para pelaku usaha dikalangan pemuda.

Data lain yang diperoleh tentang peran BPO Provinsi DIY dalam pelaksanaan aspek promosi juga peneliti amati dari hasil kuesioner. Jumlah yang diperoleh dari penelitian = 207. Jadi berdasarkan data tersebut maka tingkat persetujuan stakeholder mendekati jawaban tidak setuju, atau BPO Provinsi DIY belum menjalankan perannya dalam aspek promosi.

\section{Peran bantuan dan akses permodalan}

BPO Provinsi DIY sebagaimana informasi yang diperoleh dalam penelitian ini telah memberikan bantuan bagi peserta pelatihan keterampilan bagi pemuda berupa barang-barang serta peralatan yang dibutuhkan guna memulai sebuah usaha.

Sementara itu, untuk aspek bantuan akses permodalan sampai saat ini menurut informan dari unsur BPO Provinsi DIY kegiatan ini belum terealisasikan, meskipun sempat ada pembicaraan dengan pihak Bappeda Provinsi DIY sebagai instansi yang menangani perencanaan pembangunan untuk menindaklanjuti amanat Peraturan Pemerintah Nomor 41 tahun 2011.

Data yang dihimpun peneliti tentang peran BPO Provinsi DIY dalam pelaksanaan aspek bantuan dan akses permodalan juga peneliti amati dari hasil kuesioner. Jumlah yang diperoleh dari penelitian $=292$. Jadi berdasarkan data tersebut maka tingkat persetujuan stakeholder mendekati jawaban ragu-ragu atau netral, sehingga dinilai bahwa BPO Provinsi DIY sudah berperan pada unsur 
Muhammad Iskandar Zulkarnain -- Peran Balai Pemuda Dan Olahraga Yogyakarta Dalam Upaya Pengembangan Kewirausahaan Pemuda Untuk Mendukung Ketahanan Ekonomi Keluarga (Studi Tentang Persepsi Peserta Kegiatan Pelatihan Keterampilan BPO DIY)

pemberian modal awal namun belum berperan pada unsur penyediaan lembaga permodalan kewirausahaan pemuda.

\section{Kendala-kendala yang dihadapi}

Terdapat dua kendala yang dihadapi BPO Provensi DIY, yaitu kendala dari luar dan dalam. Kendala dari luar yang dihadapi BPO Yogyakarta dalam upaya pengembangan kewirausahaan pemuda di Yogyakarta yakni kendala keterbatasan pagu anggaran. Sedang kendala dari dalam terkait dengan pola rekrutmen peserta kegiatan, yaitu tidak adanya seleksi yang lebih selektif dalam proses rekrutmen peserta pelatihan keterampilan, sehingga pada akhirnya berdampak terhadap hasil akhir yang diharapkan yakni mewujudkan pemuda yang berwirausaha.

\section{Hasil peran BPO Yogyakarta dalam pengembangan kewirausahaan pemuda}

Hasil kajian mengenai peran Balai Pemuda dan Olahraga Provinsi Yogyakarta dalam upaya pengembangan kewirausahaan pemuda yang didasarkan pada tujuh aspek pengembangan kewirausahaan pemuda, jika didasarkan pada persepsi alumni peserta kegiatan pelatihan keterampilan BPO Provinsi Yogyakarta, maka hasil analisis skala Likert menunjukkan bahwa jumlah skor ideal (kriterium) untuk seluruh item $=5 \times 630=$ 3150, seandainya semua menjawab sangat setuju (SS). Jumlah yang diperoleh dari penelitian $=1803$. Jadi berdasarkan data tersebut maka tingkat persetujuan stakeholder mendekati jawaban ragu-ragu atau netral, sehingga dinilai bahwa BPO Provinsi DIY belum berperan sepenuhnya pada upaya pengembangan kewirausahaan pemuda .

\section{Ketahanan Ekonomi Keluarga Peserta Kegiatan Pelatihan Ketrampilan BPO Provinsi Daerah Istimewa Yogyakarta}

\section{Indikator ketahanan Ekonomi Keluarga}

Indikator yang digunakan dalam penelitian ini adalah ketahanan ekonomi keluarga yang mengacu pada pemenuhan kebutuhan fisik (physiological needs), yang merupakan kebutuhan dasar yang harus dapat dipenuhi oleh suatu keluarga. Dalam melihat keadaan dan kemampuan keluarga mencukupi kebutuhan dasar yaitu sandang, pangan dan papan digunakan perbandingan antara pendapatan yang diperoleh dari hasil wirausaha budidaya lele.

Di antara standar kemiskinan yang sudah ada seperti standar Bank Dunia, standar kemiskinan dari BPS, maupun standar dari Sajogyo, standar yang sesuai dan tepat diterapkan di Provinsi DIY adalah standar UMK (Upah Minimum Kabupaten/Kota) yang ditetapkan oleh Gubernur DIY. Adapun UMK yang ditetapkan oleh Pemerintah Provinsi DIY berbeda untuk setiap kabupaten / kota.

\section{Kontribusi pendapatan dari usaha budidaya lele}

Dari total informan sebanyak 30 orang, dan yang masih konsisten menjalankan usaha budidaya lele pasca pelatihan keterampilan budidaya lele di BPO Provinsi DIY, sebanyak 6 alumni dengan kontribusi pendapatan dari hasil budidaya lele, bahwa kontribusi ratarata pendapatan dari usaha budidaya lele sebesar Rp.3.150.000 dari total pendapatan yang diterima setiap bulannya sebanyak Rp.3.233.333. Berdasarkan kategori nilai kontribusi, rata-rata nilai kontribusi sebesar 98 persen, sehingga usaha budidaya lele yang 
dikembangkan oleh para alumni kegiatan keterampilan BPO Provinsi DIY memberikan kontribusi yang cukup besar dalam pemenuhan kebutuhan keluarga.

\section{Pendekatan pendapatan dari usaha budidaya lele dengan standar UMK}

Dalam penelitian ini besarnya pendapatan yang diperoleh dikonversikan dengan standar masing-masing UMK Rp. 988.500,- untuk Kabupaten Gunung Kidul dan Rp. 1.125.500,untuk Kabupaten Bantul. Dari total jumlah informan yang menjadi pembudidaya lele sebanyak 6 orang tersebut, semuanya dinyatakan tidak miskin atau mempunyai penghasilan di atas UMK sebagaimana ditetapkan oleh masing-masing daerah asal.

\section{Pendekatan pendapatan dari usaha non- budidaya lele dengan standar UMK}

Pada penelitian ini, selain ditemukan data bahwa di antara 30 informan ada yang masih menjalankan budidaya lele, namun ada pula yang sudah tidak menjalankan usaha budidaya lele sehingga perlu juga diketahui pendekatan pendapatan dari usaha non-budidaya lele apabila dikonversikan denganUMK. Dari 24 orang terdapat 6 orang yang memiliki penghasilan di bawah UMK dan dikategorikan miskin, sisanya 18 orang memiliki penghasilan di atas UMK yang telah ditetapkan dan dikategorikan tidak miskin.

\section{SIMPULAN}

Berdasarkan uraian tersebut di atas dapat ditarik simpulan, sebagai berikut:

Pertama, BPO Provinsi DIY dinilai berperan pada aspek penyelenggaraan pelatihan dan pemagangan. Namun pada aspek pembimbingan, pendampingan, kemitraan dan promosi belum berperan, sementara itu pada aspek bantuan dan akses permodalan BPO Provinsi DIY belum sepenuhnya berperan dikarenakan sampai saat ini belum berhasil membentuk lembaga permodalan kewirausahaan pemuda sekalipun sudah memberikan bantuan permodalan awal bagi wirausahawan muda. Dengan demikian secara keseluruhan menurut hasil penelitian menunjukkan bahwa BPO Provinsi Yogyakarya belum berperan maksimal dalam upaya pengembangan kewirausahaan pemuda

Kedua, ketahanan ekonomi keluarga dari alumni kegiatan pelatihan keterampilan BPO Provinsi DIY adalah sebagai berikut: (1) pada pengkonversian pendapatan para alumni kegiatan pelatihan keterampilan BPO Provinsi DIY yang masih menjalankan usaha budidaya lele dengan menggunakan standar UMK masing-masing daerah asal, maka disimpulkan tidak ada yang dikategorikan miskin . (2) kontribusi rata-rata pendapatan dari usaha budidaya lele sebesar 98 persen sehingga usaha budidaya lele memberikan kontribusi yang sangat besar terhadap pemenuhan kebutuhan keluarga. (3) pada pengkonversian pendapatan para alumni kegiatan pelatihan keterampilan BPO Provinsi DIY yang sudah tidak lagi menjalankan usaha budidaya lele dengan menggunakan standar UMK masingmasing daerah asal, maka disimpulkan jumlah keluarga yang masuk kategori miskin sebanyak 6 atau 25 persen dan yang dikategorikan tidak miskin sebanyak 18 atau 75 persen.

Selanjutnya disarankan hal-hal sebagai berikut:

Pertama, sudah saatnya untuk merumuskan, menghimpun dan kemudian menyususun data induk kepemudaan Provinsi DIY yang memuat data pemuda, 
Muhammad Iskandar Zulkarnain -- Peran Balai Pemuda Dan Olahraga Yogyakarta Dalam Upaya Pengembangan Kewirausahaan Pemuda Untuk Mendukung Ketahanan Ekonomi Keluarga (Studi Tentang

Persepsi Peserta Kegiatan Pelatihan Keterampilan BPO DIY)

identifikasi minat pemuda, identifikasi potensi pemuda serta analisis arah kebijakan layanan kepemudaan, sehingga dengan data induk tersebut tergambar kebutuhan layanan kepemudaan dan dengan demikian persoalan keterbatasan pagu anggaran dapat terselesaikan. Keterbatasan pagu anggaranlah yang kemudian mempengaruhi ketidakidealan volume bantuan yang diberikan BPO kepada peserta kegiatan pelatihan keterampilan yang pada akhirnya berdampak terhadap rendahnya tingkat keberhasilan dalam menjalankan usaha budidaya lele.

Kedua, rekrutmen peserta setiap kegiatan dalam upaya pengembangan kewirausahaan pemuda agar lebih berkualitas, perlu kiranya membuat standar tes bagi calon peserta sebagai syarat awal bisa mengikuti pelatihan sehingga ketika pelaksanaan kegiatan akan membuahkan hasil yang diharapkan.

Ketiga, upaya membentuk lembaga permodalan kewirausahaan pemuda, diperlukan adanya sinergi lintas instansi seperti Bappeda dan instansi terkait lainnya guna memudahkan terwujudnya lembaga yang diharapkan.

\section{DAFTAR PUSTAKA}

Friedman, MM, 1998, Keperawatan Keluarga Teori dan Parktek, Jakarta: PT Pradnya Paramita.
Kementerian Pemuda dan Olahraga, 2010, Rencana Strategis Kemenpora Tahun 2010-2014, Jakarta: Kementerian Pemuda dan Olahraga RI.

Soekanto, Soerjono., 2005, Sosiologi, Yogyakarta: Raja Grafind Persada.

Sugiyono, 2009, Metode Penelitian administrasi. Bandung: Alfabeta

World Bank, 2006, Making the New Indonesia Work for the poor, Jakarta: tanpa Penerbit.

\section{Undang-Undang dan Peraturan:}

UU Nomor 40 Tahun 2009 Tentang Kepemudaan

UU Nomor 23 Tahun 2002 Tentang Perlindungan Anak

UU Nomor 13 Tahun 2003 \Tentang Ketenagakerjaan

Peraturan Pemerintah Nomor 41 Tahun 2011 Tentang Pengembangan Kewirausahaan Dan Kepeloporan pemuda serta Penyediaan Prasarana dan Sarana Kepemudaan

Peraturan Menteri Negara Pemuda dan Olahraga Nomor 22 Tahun 2010 Tentang Rencana Strategis Kementerian Pemuda dan Olahraga Tahun 2010-2014

Surat Keputusan Gubernur DIY Nomor 279/ KEP/2013 Tentang Upah Minimum Kabupaten/Kota Tahun 2014 